\title{
Evaluation of sero-prevalence of HIV and hepatitis B co-infection among subjects in Orashi communities of Niger delta
}

\author{
Azuonwu Obioma ${ }^{1}$, Azuonwu Testimonies Chikanka²
}

Obioma A, Chikanka AT. Evaluation of sero-prevalence of HIV and hepatitis B co-infection among subjects in Orashi communities of Niger delta. Curr Res Integr Med 2017;2 (3):42- 45.

BACKGROUND: The Human Immunodeficiency Virus (HIV) and Hepatitis B virus (HBV) are two deadly diseases that could be contacted through sexual route; however, the HBV is vaccine preventable virus infection though, both have been studied and found to be capable of coinfecting elevated risk in sexual active groups and immune-compromised subjects. Studies have also shown that co-infection increases the severity of illness in an infected individual.

AIM: This study was aimed at determining the prevalence of $\mathrm{HIV} / \mathrm{HBV}$ coinfection among subjects in some Orashi Communities of Niger Delta.

METHODS: 1000 randomly selected subjects from seven locations in the area were involved in the study. The locations were Community Health Centre Edeogha-Ekpeye, Community Health Centre Ochigba, Community Health Centre Ahoada, UlaUpata community, Ahoada Timber Market, Ogbo town and Ahoada General Hospital.
RESULTS: The study population was made up of 464 males and 536 females. The total infected prevalence was $2.6 \%$; with females having $1.7 \%$ and males $0.9 \%$. Of these, $43.5 \%$ were within ages $15-24,30.4 \%$ within $25-34,17.4 \%$ within $35-44$ and $8.7 \%$ within $45-54$. Nevertheless, $74 \%$ were single while both widowed and married had $13 \%$ each.

CONCLUSION: The high prevalence among singles and person within the ages of 15-24, may probably be due to sexual promiscuity as well as the use of intravenous drugs. The study further highlight that females are more vulnerable to sexually-transmitted diseases more than their male counterparts, which may have accounted for the increased prevalence among females. Nonetheless, awareness on the means of preventing these infections such as the use of condoms and not sharing sharp objects will greatly reduce the prevalence of HIV/HBV prevalence, especially in rural areas where access to functional health facilities and affordable drugs remains a massive challenge of unprecedented proportion.

Key Words: Co-infection; HIV/HBV; Orashi communities; Awareness; Rura Areas; Risk factors
$T^{n}$ he Human Immunodeficiency Virus (HIV) is a single-stranded linear positive strand RNA virus which infects primates and replicates in the cytoplasm of its host (1). It has been known to cause adverse health conditions such as anaemia and as such has been implicated in high morbidity and mortality cases of infected subjects in Nigeria and some other countries across the globe (2). It affects and damages the body's CD4 cells and subsequently weakens the immune system respectively (3). The CD4 count in a drop of blood of a healthy individual is between 500 and 1000 whereas in an infected individual the CD4 count is often lower than 500 (4). Infection by this virus when not treated or halted, leads to a series of diseases known as Acquired Immune Deficiency Syndrome (AIDS); the virus is thus deadly when allowed to proliferate in the cells and tissues of the infected host. The damage in the health of the infected host becomes evident when the viral particle takes over the immune system of the host, thus initiate the protein synthesis to its own rather than that of the host.

Hepatitis may be literally referred to as the inflammation of the liver. About 350-400 million persons are infected with chronic hepatitis B virus worldwide while yearly, about 1 million persons die of Hepatitis B virus-related disease. Prevalence of HBV however, is between 0.15 to $20 \%(5,6)$. The possibility of developing chronic HBV infection after its acute infection differs with ages: less than $10 \%$ in adults, $90 \%$ for perinatal infection and $25-35 \%$ for persons infected at ages $1-5$ (5). The modes of transmission of the virus majorly include blood transfusion, mother to child, sexual contact, sharing of infected items (especially sharp objects). Among these, mother to child transmission plays a major role in the transmission of the virus (7). The virus has eight genotypes (A to H) out which, A and D are common in Europe (8). Complications from infection by the hepatitis $\mathrm{B}$ virus are increased with coinfection of HIV (9). In Sub-Saharan Africa, HBV is the main cause of liver carcinoma (10). Although the focus of these present study was not targeted towards ascertaining the genotypic nature and characteristics of the virus for clarity purposes.

HBV is almost 10 times more infectious than HIV, even though HIV and HBV share same endemic area and possible same routes of transmission (11). Nonetheless, in some locations, a blood marker of present or past
HBV infection is found in about two-thirds of all HIV-infected persons as reported by some researchers (9). Also, gays have a higher chance of HBV/ HIV coinfection compared with heterosexuals and intravenous drug users (12). According to WHO (13), the prevalence of HIV/HBV among men having sex with men is $6.1 \%$ while among intravenous drug users is $7 \%$. The worldwide prevalence of HBV/HIV co-infection is $7.4 \%$. Of the 36.7 million persons living with HIV, 2.7 million are also infected with HBV. Furthermore, $71 \%$ of these infected persons are found in Sub-Saharan Africa (14).

In most rural areas in Nigeria, little or no attention is paid to public health outcome and when persons took ill, the most implicated differential is malaria or typhoid fever and so, most vulnerable subjects resorts to either herbal remedy treatment or roadside chemists without first knowing the cause of the illness through detailed and accurate laboratory diagnosis, which should be followed with a prescription from a potentially trained expertise. It is not until the illness become critical that they visit the health facility for medical attention. Nonetheless, it is strongly believed that both HIV and HBV can survive in their host cell without any visible clinical sign for a long period of time. There seems to be limited resources of information with respect to the epidemiological data of the co-infection of HIV/HBV infection in the remote communities of Niger Delta, thus the important of this study cannot be underscored as this material point in time, as data generated will be useful in the provision of the epidemiological data that will help in health planning and stimulate much needed actions that will help in the management and control of further epidemic outbreak in remote settings, even as public health awareness on the subject matter will be strongly underpinned in the end.

\section{METHODS}

The subjects for this study were drawn from seven locations within AhoadaEast Local Government Area (LGA), which is one of the 23 LGAs in Rivers State in the oil-rich Niger Delta Region. It is a rural area whose dwellers are predominantly farmers and traders while some are involved in fishing. They belong to the Ekpeye Kingdom. Oil exploration and marketing are two major activities for which the area is known. It is surrounded by communities such as Rumuekpe, Obagi, Obricom, Elele, Omoku and Ahoada West Local

${ }^{1}$ Faculty of Science, Department of Medical Laboratory Science, Rivers State University of Science and Technology, Nigeria, ${ }^{2}$ Faculty of Science, Department of Applied and Environmental Biology, Rivers State University of Science and Technology, Nigeria.

Correspondence: Dr. Azuonwu Obioma, Faculty of Science, Department of Medical Laboratory Science, Rivers State University of Science and Technology Nkpolu Orowhorukwo, Port Harcourt, Nigeria, Telephone 234 803551968, e-mail bimajacobs@yahoo.co.uk

Received: November 06, 2017, Accepted: December 06, 2017, Published: December 25, 2017 
Government Area which are also involved in oil exploration activities. These have increased its population as most persons prefer working in oil exploration companies rather than farming or fishing.

\section{Inclusion criteria}

The recruited subjects must be willing to participate through expressly given their consent to be involved. The must be 15 years and above and are resident in any of the communities that are involved in the study. Only apparently health subjects with no known case of already diagnosed HBV/HIV infected subjects were allowed to be involved.

\section{Exclusion criteria}

Those who never consented to participate were deliberately removed from the study. Also subjects who are below the age of 15 years were also removed from the study. Those who are not permanently residing in the communities where the study was conducted were not allowed to participate in the study. Already diagnosed and confirmed infected subjects were completely removed from the study.

\section{Sample collection}

Blood samples were aseptically collected from 1000 randomly selected apparently healthy subjects within the area that visited the health facilities. The subjects were drawn from the Community Health Centre EdeoghaEkpeye (Location 1), Community Health Centre Ochigba (Location 2), Community Health Centre Ahoada (location 3), Ula-Upata community (Location 4), Ahoada Timber Market (Location 5), Ogbo town (Location 6) and Ahoada General Hospital (Location 7).

Blood samples $(3 \mathrm{ml})$ were collected from the anticubital veins of the subjects, it was pipetted into a serum bottle and left to clot. Centrifugation of the sample was carried out and the serum recovered and used immediately for serological assay. All procedures are done aseptically and according to manufacturer's instruction.

\section{HIV 1 and HIV 2 detection}

Collected sera were assayed for HIV 1 and 2 using the Determine and Stat-Pak HIV 1 and 2 kits which is a double enzyme-linked immunosorbent assay. The Determine kit is used for the in vitro qualitative detection of HIV antibodies in human sera. The positive ones are then confirmed using the Stat-Pak HIV 1 and 2 which is based on the principle of immune chromatography. It uses a combination of specific antibody binding protein conjugated to a colloidal gold dye particle and HIV 1 and 2 antigens bound to the membrane's solid phase. In a positive test, the dye conjugated immune complex migrates on the nitrocellulose membrane and captured by the antigens immobilized in the test membrane, producing a purple or pink line. The Standard Diagnostics Bioline HIV 1 and 2 kit which is a rapid immunochromatographic test was used in separating subtype 1 and 2. Although whole blood and plasma can be used, serum was however used in this study for clarity sake devoid of interference of the blood component. The kit was used according to manufacturer's instruction respectively.

\section{Hepatitis B surface antigen assay}

Acon HBsAg test strips purchased from Acon laboratories Inc, San Diego, USA were used in detecting the presence of $\mathrm{HBsAg}$ from the recovered sera. The strip is a rapid chromatographic immunoassay used in the determination of HBsAg in serum qualitatively. The process was carried out according to manufacturer's instruction. The appearance of a control line in a positive or negative result shows or confirms the validity of the test.

\section{Statistical analysis}

Analysis of data from the results was done using the Statistical Package for Social Sciences (SPSS 20) and the results represented in tables and charts accordingly.

\section{RESULTS}

\section{Studies identified}

In this study, 1000 subjects were involved out of which 464 were males and 536 were females. The total prevalence was $2.6 \%$ with females having $1.7 \%$ while males made up $0.9 \%$. Of the total prevalence, $43.5 \%$ were within ages $15-24,30.4 \%$ within $25-34,17.4 \%$ within $35-44$ and $8.7 \%$ within $45-54.74 \%$ were single, $13 \%$ widowed and the remaining $13 \%$ were married. The figures below represent these results (Figures 1 -3).

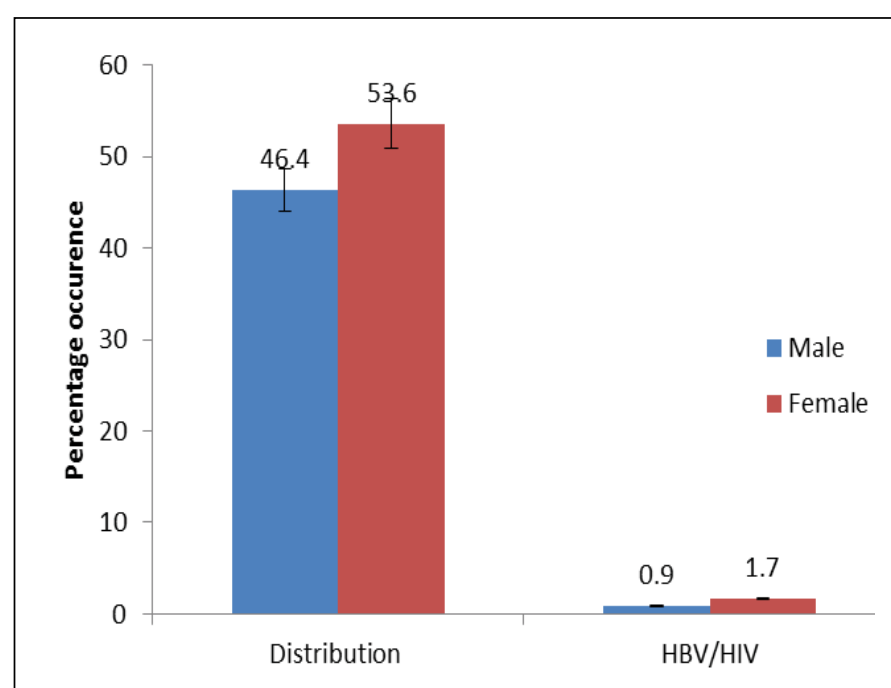

Figure 1) Distribution and Prevalence of HBV/HIV co-infection based on gender

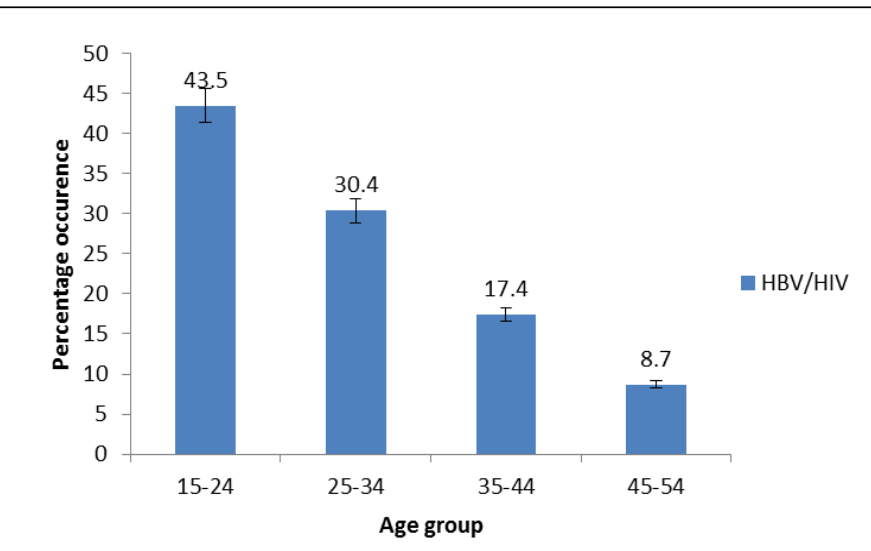

Figure 2) Prevalence of $\mathrm{HBV} / \mathrm{HIV}$ co-infection based on age

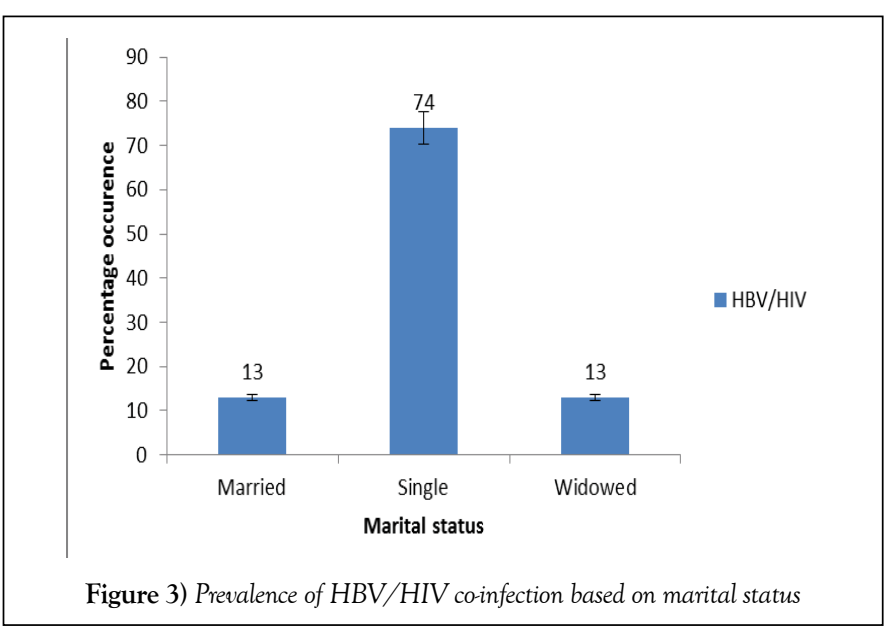

\section{DISCUSSION}

The Human Immunodeficiency Virus (HIV) and Hepatitis B Virus both have similar modes of transmission. Although it is possible for a person to be infected with only one of this pathogen, nonetheless, co-infection by these two viruses is becoming increasingly popular; as such a regular surveillance on its prevalence status is required more often. It is thus important that persons with HBV be diagnosed for HIV also because the presence of HIV increases the progression of HBV (8). This study was carried out in selected communities in Ahoada-East Local Government Area of Niger Delta to determine the prevalence of HIV/HBV co-infection in the area. A total prevalence of $2.6 \%$ was recorded. It should be noted that majority of the subjects used were subjects who visited the health facilities and the 
probability of more persons not diagnosed having the co-infection cannot be ruled out. Most times, due to poverty some persons do not visit the health facility for fear of spending money probably and would rather fall back to native treatment option. Secondly, the fear of knowing the illness one has can even kill faster than the disease itself and so most persons would rather not visit the health facility to be diagnosed to avoid that fear and anxiety of stigmatization. Thirdly, a negative test result may not necessarily mean than the subject is not infected as a false negative result may be obtained especially if the test was carried out just after infection (15).

This study recorded a high prevalence among females (1.7\%) than males; although the number of female subjects used in the study was more than males, However, evidence based study in the past had also reported that globally females especially young ones are four time more prone to HIV infection than males, given their biological anatomical architecture as endowed by nature (16), thus female vagina had greater area of susceptible tissues especially in young female adult whose vagina may not have been fully developed, hence they are prone to risk of laceration during unprotected hash sexual intercourse, probably with a mature male adult with fully developed organs (17). Nevertheless, such laceration may occur during forceful sexual engagement or rape of young female adults in remote communities. Nonetheless, it is probably believed that the promiscuity of some females especially in the quest for financial benefits cannot be overemphasized. Since multinational and even local oil exploration workers are frequently in the area, the females may be lured into unprotected sex by the mere promises of money; in most cases, the HBV/HIV status of both individuals are not known, and so if one is infected, transmission may occur (18). Also, some females are inclined to having multiple sex partners, indulge in prostitution while some may also be victim of raped as young girls are often seen hawking food and other consumables on the street to assist their parents in the provision of family food and payments of their bills, due to increasingly visibility of poverty among the majority of the subjects in the remote communities. Most of these subjects are not educated and so when they visit salons to fix their hair, needles that have been used on an infected lady's head may also be used for them without objection. Also, during fixing of nails, if the sharp instrument used is not properly sterilized, there is the possibility of transfer of both HIV and HBV to the unsuspected subject.

However, subjects within the ages of $15-24$ had a higher prevalence rate compared with the three other age groups. This group is made up teenagers and adolescents who more often indulge in illicit practices such as intravenous drug use, risky behaviours and most times they engage in risky sexual activities without the use of condom for protection, even under the colossal influence of an alcohol. Also, there is the possibility of them sharing sharp objects such as clippers and razors while shaving. These actions predispose them to HBV/HIV co-infection. Furthermore, it is most likely that the infected adolescents must have acquired the virus through their infected mother during birth over time, especially in endemic areas like the developing communities where access to functional health care facility and robust health education outcome is lacking among subjects, though this was not the focus of the research.

It is often said that singles (especially) those living in the rural areas are prone to exploring various life-threatening activities as they feel they may not be accountable to anyone. Some of them have multiple sexual behaviours and share sharp objects (females who live in the same home may most likely share shaving sticks used in shaving their pubic region and even razors used in shaving their eyebrows). These are potentially massive risk factors that predispose any one to colossal co-infection

\section{CONCLUSION}

This study was carried out on 1000 subjects drawn from seven locations in Ahoada East Local Government Area of Rivers State. 53.6\% were females while $46.4 \%$ were males. It recorded an HBV/HIV co-infection rate of $2.6 \%$ with females having $1.7 \%$ while males made up $0.9 \%$. Majority of those with co-infection were singles and within ages 15-24. Increased prevalence among these three groups (singles, females and ages 15-24) has been linked to sexual promiscuity, sharing of sharp objects and rape.

\section{RECOMMENDATIONS}

It is worthy of note that most anti-HBV drugs such as tenofovir are also active against HIV as such can serve as dual treatment option against HIV and HBV. This drug should be made available for persons with HBV/HIV co-infection. Preventive measures such as not sharing sharp objects and not having multiple sexual partners should be practiced. While visiting salons, it is important that one has his/her instruments, especially the sharp ones.
Awareness on regular HBV/HIV serological testing should be carried out so as to enable each person know his/her status. Blood to be used for transfusion must be screened for both viruses. Medical workers should also be cautious of hospital-acquired infections that are linked to occupational hazard.

\section{ACKNOWLEDGEMENT}

The author would like to appreciate the support and continues prayers of Dr. Azuonwu Goodluck, Mrs. Azuonwu Matilta, Azuonwu Benneth, Dr. G.N Wokem, and Prof E.C Chuku. Furthermore, we also wish to thank all the subjects that participated in the study, even as the co-operation and assistant of all the laboratory staff are strongly appreciated.

\section{ETHICAL CONSIDERATION}

All the subjects that participated in the research study gave their consent to participate in the study after the detailed focus and aim of the study was explained to them. The ethical approval for the study was sought and approval was granted by the ethical committee of the Department of Medical Laboratory Science, Rivers State University and the laboratory unit of the health centers were the assay were performed.

\section{REFERENCES}

1. Prescott LM, Harley JP, Klein DA. Microbiology, 7th Edition. McGraw Hill, New York. 2008; 416

2. Ejele OA, Nwauche CA, Erhabor O. The prevalence of hepatitis B surface antigenaemia in HIV positive patients in the Niger delta of Nigeria. Niger J Med 2004;13:175-179.

3. Imade GE, Badung B, Pam S. Comparism of a new affordable flow cytometric method and the manual magnetic beed technique for CD4 T- lymphocyte counting in laboratory. Immunology 2005;12:122-227.

4. Mermin J, Lule J, Ekwaru J. Association between malaria and CD4 cell count decline among persons with HIV. J Acquir Immune Defic Syndr 2005;41:129-130.

5. McMahon BJ. Epidemiology and natural history of hepatitis B. Semin Liver Dis 2005;25:3-8.

6. Custer B, Sullivan SD, Hazlet TK, et al. Global epidemiology of hepatitis $\mathrm{B}$ virus. J Clin Gastroenterol 2004;38:S158-S168.

7. Liaw YF, Brunetto MR, Hadziyannis S. The natural history of chronic HBV infection and geographical differences. Antivir Ther 2010;15:25-33.

8. World Health Organization. Management of hepatitis B and HIV coinfection. Clinical Protocol for the WHO European Region 2011.

9. Thio CL1, Seaberg EC, Skolasky R Jr, et al. HIV-1, hepatitis B virus and risk of liver-related mortality in the Multicenter Cohort Study (MACS). Lancet 2002;360:1921-1926.

10. Lavanchy D. Hepatitis B virus epidemiology, disease burden, treatment and current and emerging prevention and control measures. J Viral Hepat 2004;11:97-107.

11. Tarantola A, Abiteboul D, Rachline A. Infection risks following accidental exposure to blood or body fluids in health care workers: A review of pathogens transmitted in published cases. Am J Infect Control 2006;34:367-375.

12. Konopnicki D, Mocroft A, De Wit S, et al. Hepatitis B and HIV prevalence, AIDS progression, response to highly activeJantiretroviral therapy and increased mortality in the EuroSIDA cohort. AIDS 2005; 19:593-601.

13. World Health Organization. Global hepatitis report 2017;1-9.

14. Easterbrook P, Platt L, Gower E, et al. Global systematic review and meta-analysis of the sero-prevalence of HBV and HCV infection in HIV infected persons. $8^{\text {th }}$ IAS Conference on Pathogenesis, Treatment and Prevention, Vancouver, Canada 2015.

15. WHO/UNAIDS/UNICEF. Towards universal access: Scaling up priority HIV/AIDS Intervention in the health sector. Progress Report, WHO, Geneva 2008.

16. Obi A, Osaro E, Nnenna FP. Socio-demographic characteristics of adults screened for human immunodeficiency virus infection in Ahoada-East local government area in the Niger delta of Nigeria. J Glob Infect Dis. 2011;3:334-338 
Obioma et al

17. Cynthia AG, Barbara VM. Gender, culture and power: Barriers to HIV prevention strategies for women. J Sex Res 1999;33:355-362.

18. Azuonwu O, Ihua A, Wokem GH, et al. Prevalence of Human
Immunodeficiency Virus (HIV) antibody among subjects in Ogba/ Egbema/Ndoni Local Government Area (LGA) of Rivers State of Nigeria. Translational Biomed 2017;8:118 